\title{
Distribution and molecular characterization of biosurfactant-producing bacteria
}

\author{
NASSIR ABDULLAH ALYOUSIF ${ }^{1, \bullet}$, YASIN Y.Y.AL LUAIBI ${ }^{2}$, WIJDAN HUSSEIN ${ }^{2}$ \\ ${ }^{1}$ Department of Ecology, College of Science, University of Basrah. Basrah, Iraq. Tel.: +964-780-7038010, `email: nassirmicro@gmail.com \\ ${ }^{2}$ Department of Biology, College of Science, University of Basrah. Basrah, Iraq \\ Manuscript received: 4 July 2020. Revision accepted: 10 August 2020.
}

\begin{abstract}
Alyousif NA, Luaibi YYYA, Hussein W. 2020. Distribution and molecular characterization of biosurfactant-producing bacteria. Biodiversitas 21: 4034-4040. Biosurfactants (BSs) are biological surface-active compounds produced by several microorganisms with many areas of application, as such become an important product in biotechnology and consequence to be used in industries. In recent years, many researchers pay attention to BSs producers' microorganisms. The present study was aimed to isolate, identify, and screening BS producing bacteria from six various sites in two different cities in Iraq. Four samples were collected from four sites in Basrah governorate and the rest two samples from Al-Garraf oilfield in Thi-Qar governorate. A total of 33 different bacterial isolates were obtained, 20 out of the 33 were found to be biosurfactants producing isolates that detected through the emulsification index (E24\%), oil spreading test, and emulsification activity. The isolated bacterial strains were more identified by $16 \mathrm{~S}$ rRNA gene sequencing. The results showed that the biosurfactants producing isolates belonged to genera Bacillus, Pseudomonas, Enterobacter, Staphylococcus, Acinetobacter, and Aerococcus. Bacillus jeotgali and Aerococcus viridans are reporting as biosurfactant producing bacteria for the first time and Bacillus jeotgali is isolated for first time from crude oil of oilfield reservoir in this study in world. Moreover, six bacterial isolates were identified as new strains and deposited at NCBI Genbank under accession numbers MT261834 (Bacillus subtilis strain IRQNWYA3), MT261835 (Bacillus licheniformis strain IRQNWYB4), MT261836 (Pseudomonas stutzeri strain IRQNWYF2), MT261837 (Pseudomonas zhaodongensis strain IRQNWYF3), MT261838 (Pseudomonas sp. IRQNWYF4) and MT261839 (Bacillus licheniformis strain IRQNWYF5). A2 isolate that was identified as Pseudomonas aeruginosa has shown the highest values of emulsification activity and emulsification index $(1.678 \pm 0.050$ absorbance at $540 \mathrm{~nm}$ and $56.6 \%$ respectively) that show efficient potential of biosurfactant production. Phylogenetic tree was also constructed in this study based on $16 \mathrm{~S}$ rRNA gene sequences of biosurfactant-producing bacteria to evaluate their close relationship and evolution between them.
\end{abstract}

Keywords: 16S rRNA gene sequencing, biosurfactant-producing bacteria, emulsification activity

\section{INTRODUCTION}

Biosurfactants (BSs) are biological surface-active compounds produced by several microorganisms which either secreted into the surrounding environment or adhere to the plasma membrane of the producer cell (Antoniou et al. 2015; Ndlovu et al. 2016). BSs have unique properties such as high surface activity, non-toxic nature, environmentally friendly, biodegradable, and tolerance of extreme temperatures, $\mathrm{pH}$, and salinity. These properties allow biosurfactants to be a preferable alternative to chemical surfactants (Thavasi et al. 2011; Liu et al. 2013).

Biosurfactants are amphipathic molecules containing two moieties, hydrophobic moiety having long-chain of fatty acids, which is less soluble in water and a hydrophilic part having carbohydrates or carboxylic acids, which is more soluble in water. They are divided into diverse types based on chemical structure, namely: glycolipids, phospholipids, lipopeptides, neutral lipids, fatty acids, and polymeric biosurfactants (Banat et al. 2014; Soltanighias et al. 2019).

Biosurfactants producing bacteria are ubiquitous and inhabiting several environments in a wide range of temperatures, $\mathrm{pH}$ values, and salinity. Several bacterial belong to different genera such as Bacillus, Pseudomonas,
Burkholderia and Flavobacterium are reported to produce biosurfactants, however, the bacteria are considered generously biosurfactant producers. The soil and water contaminated with hydrocarbons and oilfields produced water is abundant in biosurfactant producing bacteria, where they produce biosurfactants to exploit hydrocarbons as a carbon source (Femi-Ola et al. 2015; Ewida and Mohamed 2019; Sohail and Jamil 2020).

BSs have gained much interest in recent years which considered as one of the high values of microbial products, that have many areas of application and become an important product of biotechnology that can be used in industries, environmental and medical application as antimicrobial, wetting, coagulating, anti-adhesive, thickening, dispersion, moisturizing, foaming, emulsifiers and agents, where BSs have exploited in various industries such as enhanced oil recovery, medicine, food processing, agriculture, pharmaceutical, cosmetics and bioremediation of organic pollutants in the environment (Vedaraman and Venkatesh 2011; Elazzazy et al. 2015).

The aim of this study is to isolate and screen biosurfactants producing bacteria from different sources, characterize bacteria by molecular technique, determine their potential to produce biosurfactants, and construct phylogenetic tree. 


\section{MATERIALS AND METHODS}

\section{Samples collection}

Soil, water and crude oil samples were collected from six sites (soil sample from the area around the generator (A), soil sample from the area around the petrol station (B), produced water from Al-Garraf oilfield (C), crude oil from Al-Garraf oilfield (D), contaminated water from Shatt AlArab (E) and soil sample from area around Nehran Omer oilfield (F). A, B, E and F sites in Basrah governorate $\left(30^{\circ} 22^{\prime} \mathrm{N} 47^{\circ} 22^{\prime} \mathrm{E}\right)$, while $\mathrm{C}$ and $\mathrm{D}$ in Thi-Qar governorate $\left(31^{\circ} 14^{\prime} \mathrm{N} 46^{\circ} 19^{\prime} \mathrm{E}\right)$. Ten grams Soil samples were collected from five points under depth five $\mathrm{cm}$ using a sterile shovel and placed in sterile containers, while $500 \mathrm{ml}$ of water samples and $500 \mathrm{ml}$ of crude oil samples were collected. Then, all samples were transferred in a cool box to the laboratory for the investigation.

\section{Isolation of biosurfactant-producing bacteria}

Isolation of biosurfactant-producing bacterial strain was conducted by enrichment method using modified mineral salt medium (MSM) adopted from Deng et al. (2014). The MSM has consisted of $\mathrm{g} / \mathrm{l}$ of $5 \mathrm{NaCl}, 3$ of $\mathrm{Na}_{2} \mathrm{HPO}_{4}, 2$ of $\mathrm{KH}_{2} \mathrm{PO}_{4}$, 1 of $\mathrm{NH}_{4} \mathrm{NO}_{3}, 0.7$ of $\mathrm{MgSO}_{4} .7 \mathrm{H}_{2} \mathrm{O}$, and $1 \mathrm{ml} / 1$ trace salt solution with $1 \%(\mathrm{v} / \mathrm{v})$ olive oil as the sole carbon source and $\mathrm{pH}$ 7. The trace salt solution was defined in $\mathrm{mg}$ of $20 \mathrm{CaCl}_{2}, 30$ of $\mathrm{FeCl}_{3}, \quad 0.5$ of $\mathrm{CuSO}_{4}, \quad 0.5$ of $\mathrm{MnSO}_{4} \cdot \mathrm{H}_{2} \mathrm{O}$, and 10 of $\mathrm{ZnSO}_{4} .7 \mathrm{H}_{2} \mathrm{O}$ per liter. The MSM was sterilized by autoclaving at $121{ }^{\circ} \mathrm{C}$ for $20 \mathrm{~min}$. Two grams of the soil samples and $2 \mathrm{ml}$ of contaminated water samples were enriched separately with $50 \mathrm{ml}$ of MSM in $250 \mathrm{ml}$ conical flasks supplied with $1 \%$ olive oil. The Erlenmeyer flask was incubated at $30{ }^{\circ} \mathrm{C}$ and $150 \mathrm{rpm}$ for 7 days. The enrichment culture products were sequentially diluted, and spread on the nutrient agar (without olive oil) for incubation at $30{ }^{\circ} \mathrm{C}$. After $24 \mathrm{hrs}$, the colonies with different morphologies were picked out and purified based on their Gram staining characteristic, cell shape, and colony morphology. The bacteria were maintained on nutrient agar slants and stored at $4{ }^{\circ} \mathrm{C}$.

\section{Preparation of the bacterial inoculum}

The isolated bacteria were activated in fifty $\mathrm{ml}$ of autoclaved nutrient broth in 250-ml flasks and incubated for $24 \mathrm{hrs}$ at $30{ }^{\circ} \mathrm{C}$. The uninoculated nutrient broth was used as a negative control. The MSM containing Erlenmeyer's flasks were inoculated with $5 \% \mathrm{cfu} / \mathrm{ml}$ of the prepared bacterial inoculum (OD600, 1).

\section{Screening for biosurfactant production}

For screening biosurfactant production by the isolated bacteria, $50 \mathrm{ml}$ MSM with $1 \%$ of olive oil as carbon source in $250 \mathrm{ml}$ Erlenmeyer flasks was inoculated with $5 \%$ inoculum and incubated in a rotary shaker at $30^{\circ} \mathrm{C}$ and 150 rpm for 7 days. After 7 days of fermentation, bacterial cells were removed by centrifugation $5000 \mathrm{rpm}$ at $4 \mathrm{C}^{\circ}$ for 20 min (Xiangsheng et al. 2010). The cell-free supernatant was subjected to different screening methods to obtain biosurfactant-producing strains.

\section{Oil spreading test}

The oil spreading test was carried out by adding $40 \mathrm{ml}$ of distilled water to a Petri dish with a diameter of $15 \mathrm{~cm}$. Subsequently $20 \mu \mathrm{l}$ of crude oil was added onto the surface of the water, which was formed a thin layer. Then, $10 \mu \mathrm{l}$ of culture supernatant was added onto the center of the crude oil layer. The area of the clear zone on the oil surface was measured and compared with $10 \mu \mathrm{l}$ of distilled water as a negative control (Satpute et al. 2010).

\section{Determination of the emulsification index}

A mixture of two $\mathrm{ml}$ supernatant and two $\mathrm{ml}$ kerosene was vertically stirred for two min and the height of the emulsion layer was measured after $24 \mathrm{hrs}$ to determine the emulsification index (Ozdal et al. 2017). The equation used to determine the emulsification index (E24\%) is as follows:

$$
\text { E24 }(\%)=\frac{\text { The height of emulsion layer } \times 100 \%}{\text { The height of total solution }}
$$

\section{Determination of emulsification activity}

Cell-free supernatant $(0.5 \mathrm{ml})$ of the sample was added to a screw-capped tube containing $7.5 \mathrm{ml}$ of Tris-Mg [20mM Tris $\mathrm{HCl}(\mathrm{pH} 7.0)$ and $10 \mathrm{mM} \mathrm{MgSO}$ ] and $0.1 \mathrm{ml}$ of kerosene. The tubes were vortexed for $2 \mathrm{~min}$ and allowed to sit for 1 hour. Absorbance was measured at 540 $\mathrm{nm}$. Emulsification activity (EA) was defined as the measured optical density (Sifour et al. 2005).

\section{Biomass determination}

Biomass was determined by centrifuging $10 \mathrm{ml}$ samples at $5000 \mathrm{rpm}$ for $15 \mathrm{~min}$ at $5{ }^{\circ} \mathrm{C}$ and the cell pellet was dried in an oven at $105^{\circ} \mathrm{C}$ for $24 \mathrm{hrs}$ (Santos et al. 2018).

\section{Bacterial identification by $16 \mathrm{~S}$ rRNA}

The bacterial isolates were identified up to species level by targeting 16S rRNA gene. Chromosomal DNA was extracted according to the procedure of Presto ${ }^{\mathrm{TM}}$ Mini $\mathrm{g}$ DNA bacteria kit from the (Geneaid) company. DNA was amplified by the polymerase chain reaction (PCR) using universal primers 27F (5-AGAGTTTGATCCTGGCTCAG3) and 1492R (5-GGTTACCTTGTTACGACTT-3). PCR Reactions were made in a total volume of $50 \mu$ l. An initial denaturation step of $96^{\circ} \mathrm{C}$ for $3 \mathrm{~min}$ followed by 27 cycles of $96^{\circ} \mathrm{C}$ for $30 \mathrm{~s}$, annealing temperature of $56^{\circ} \mathrm{C}$ for $25 \mathrm{~s}$ and extension at $72^{\circ} \mathrm{C}$ for $15 \mathrm{~s}$ and final extension at $72^{\circ} \mathrm{C}$ for 10 min (Miyoshi et al. 2005). PCR products were separated based on molecular weight using a $1 \%(\mathrm{w} / \mathrm{v})$ agarose gel made with TBE buffer (Thermo Fisher Scientific). DNA was visualized under UV light using ethidium bromide DNA stain (Thermo Fisher Scientific). Amplified DNA was purified and sequenced by Macrogen company (South Korea). The obtained 16S rRNA gene sequences were corrected and compared with nucleotide sequences of NCBI using BLAST tools "http://www.ncbi.nlm.nih.gov" to estimate the sequence homology and identification of isolates. Multiple sequence alignment was performed using CLUSTAL Omega "https://www.ebi.ac.uk/Tools/msa/clustalo/". The phylogenetic tree was constructed using MAFFT (Multiple alignment program for nucleotides sequences) "http://mafft.cbrc.jp/alignment/server/“ (Katoh et al. 2002). 
Table 1. Screening of bacterial isolates for biosurfactant production

\begin{tabular}{|c|c|c|c|c|c|c|}
\hline Site & 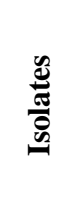 & 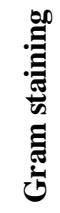 & 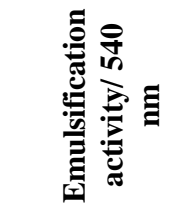 & 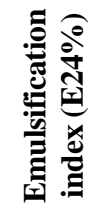 & 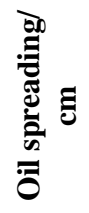 & 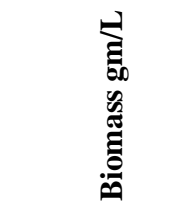 \\
\hline \multirow[t]{6}{*}{ A } & A1 & - & $0.741 \pm 0.050 *$ & 53.3 & 12 & $2.787 \pm 0.002 *$ \\
\hline & $\mathrm{A} 2$ & - & $1.678 \pm 0.050$ & 56.6 & 14 & $2.787 \pm 0.100$ \\
\hline & A3 & + & $0.353 \pm 0.055$ & - & - & $1.142 \pm 0.344$ \\
\hline & A4 & + & $0.048 \pm 0.006$ & 10 & 4 & $3.268 \pm 0.583$ \\
\hline & A5 & - & $0.038 \pm 0.038$ & - & - & $0.942 \pm 0.363$ \\
\hline & A6 & + & $0.050 \pm 0.038$ & - & 0.4 & $1.413 \pm 0.163$ \\
\hline \multirow[t]{6}{*}{ B } & B1 & + & $0.051 \pm 0.009$ & 13.3 & 3 & $2.704 \pm 0.111$ \\
\hline & B2 & - & $0.041 \pm 0.007$ & - & 0.2 & $1.664 \pm 0.433$ \\
\hline & B3 & + & $0.041 \pm 0.003$ & - & - & $0.612 \pm 0.248$ \\
\hline & B4 & + & $0.271 \pm 0.041$ & 10 & 3 & $2.752 \pm 0.526$ \\
\hline & B5 & + & $0.294 \pm 0.017$ & 13.3 & 5.5 & $2.864 \pm 0.123$ \\
\hline & B6 & - & $0.048 \pm 0.003$ & 16.6 & 5 & $2.681 \pm 0.342$ \\
\hline \multirow[t]{5}{*}{$\mathrm{C}$} & $\mathrm{C} 1$ & - & $0.011 \pm 0.008$ & - & - & $1.468 \pm 0.319$ \\
\hline & $\mathrm{C} 2$ & - & $0.062 \pm 0.009$ & - & - & $0.750 \pm 0.227$ \\
\hline & $\mathrm{C} 3$ & + & $0.065 \pm 0.008$ & 40 & 3 & $3.369 \pm 0.557$ \\
\hline & $\mathrm{C} 4$ & - & $0.054 \pm 0.010$ & 16.6 & 5 & $3.559 \pm 0.469$ \\
\hline & $\mathrm{C} 5$ & + & $1.197 \pm 0.195$ & 40 & 10 & $2.355 \pm 0.144$ \\
\hline \multirow[t]{4}{*}{$\mathrm{D}$} & D1 & + & $0.868 \pm 0.103$ & 30 & 5.5 & $3.307 \pm 0.289$ \\
\hline & D2 & + & $0.896 \pm 0.082$ & 53.3 & 14 & $2.237 \pm 0.080$ \\
\hline & D3 & + & $0.064 \pm 0.009$ & 13.3 & 2 & $2.297 \pm 0.111$ \\
\hline & D4 & - & $1.461 \pm 0.094$ & 53.3 & 12 & $3.435 \pm 0.375$ \\
\hline \multirow[t]{7}{*}{$\mathrm{E}$} & E1 & - & $0.480 \pm 0.007$ & 10 & 4 & $3.268 \pm 0.583$ \\
\hline & $\mathrm{E} 2$ & - & $0.048 \pm 0.011$ & 13.3 & 2 & $3.269 \pm 0.145$ \\
\hline & E3 & - & $0.031 \pm 0.002$ & - & 0.3 & $1.062 \pm 0.212$ \\
\hline & E4 & - & $0.011 \pm 0.005$ & - & - & $0.767 \pm 0.061$ \\
\hline & E5 & - & $0.038 \pm 0.006$ & - & - & $0.724 \pm 0.303$ \\
\hline & E6 & - & $0.049 \pm 0.003$ & - & 0.2 & $1.621 \pm 0.375$ \\
\hline & E7 & - & $0.045 \pm 0.003$ & 16.6 & 4 & $2.947 \pm 0.246$ \\
\hline \multirow[t]{5}{*}{$\mathrm{F}$} & $\mathrm{F} 1$ & + & $0.198 \pm 0.069$ & 10 & 3 & $1.760 \pm 0.153$ \\
\hline & $\mathrm{F} 2$ & - & $0.020 \pm 0.012$ & 30 & 5.9 & $1.819 \pm 0.246$ \\
\hline & F3 & - & $0.051 \pm 0.009$ & - & - & $0.849 \pm 0.102$ \\
\hline & $\mathrm{F} 4$ & - & $0.087 \pm 0.005$ & 10 & 2.5 & $3.268 \pm 0.144$ \\
\hline & F5 & + & $0.028 \pm 0.003$ & - & - & $0.435 \pm 0.257$ \\
\hline
\end{tabular}

Note: Mean $\pm \mathrm{SD}, \mathrm{n}=3$

\section{Statistical analysis}

The average values presented in emulsification activity and biomass were estimated by triplicate and expressed as mean \pm standard deviation.

\section{RESULTS AND DISCUSSION}

\section{Isolation of bacteria}

The six samples of different sources in the present study had used to isolate the bacteria. Thirty-three bacterial isolates were isolated by enrichment culture techniques from collected samples. The Gram staining and microscopic measurements of bacterial cells were recorded $19(57.57 \%)$ Gram-negative isolates and $14(42.43 \%)$ Gram-positive isolates. Number of bacterial isolates in each site were distributed as follows: 6 isolated from soil sample of A-site (3-ve and 3+ve), 6 from soil sample of B site (2 -ve and $4+v e), 5$ from soil sample of $C$ site $(3$-ve and 2 +ve), 4 from water sample of D site ( 3 +ve and 1 -ve), 7 from water sample of $\mathrm{E}$ site $(7-\mathrm{ve})$ and 5 from crude oil of F site ( 3 -ve and $2+$ ve) (Table 1$)$.

\section{Screening of biosurfactant producing bacteria}

Qualitative screening tests (emulsification index and Oil spreading test) and quantitative test (emulsification activity) were performed to assess biosurfactant production by bacterial isolates. The Emulsification index (E24\%) referred to that $20(60.6 \%)$ isolates (out of 33) could emulsify the kerosene with values ranging from $56.6 \%$ to $10 \%$ and considered positive for biosurfactant production (Table 1). Out of the 33 bacterial isolates screened for the oil spreading test, 24 isolates $(72.7 \%)$ showed a clear zone of oil displacement with diameters were ranging from 14 to $0.2 \mathrm{~cm}$ (Table 1), but the four isolates (A6, B2, E3, and E6) are negative for the emulsification index and showed weak positive results $(0.4,0.2,0.3$ and $0.2 \mathrm{~cm})$ for the oil spreading test, therefore, they considered negative for biosurfactant production. Quantitative tests (emulsification activity) were analyzed for each isolate to determine which isolates are active producers for biosurfactant. The results showed that A2, D4, C5, D2, D1 and A1 isolates have the highest values of emulsification activity. A2 isolate shows efficient potential of biosurfactant production and can be used for future applications. Higher biomass concentration was obtained from biosurfactant producing isolates than non-producing bacteria.

Twenty isolates $(60.6 \%)$ were determined as biosurfactant producing bacteria according to screening tests distributed among the sampling sites including 10 Gram-negative isolates A1, A2, B2, B6, C4, D4, E1, E2, $\mathrm{E} 7$ and F2, and 10 Gram-positive isolates A4, B1, B4, B5, C4, D1, D2, D3, F1, and F4. All bacterial isolates of AlGarraf oilfield crude oil showed the ability of biosurfactant production.

\section{Bacterial identification by $16 \mathrm{~S}$ rRNA}

All bacterial species were identified by amplification and sequencing of the $16 \mathrm{~S}$ rRNA gene. The sequences were analyzed by using Basic Local Alignment Search Tool (BLAST) followed by the National Center for Biotechnology Information (NCBI) "http://www.ncbi.nlm.nih.gov".

The 16S rRNA gene sequence analysis of all the bacterial isolates demonstrates that these isolates at genus level (Figure 1) belongs to: Bacillus (11 isolates), Pseudomonas (8 isolates), Enterobacter (6 isolates), Aerococcus (2 isolates), Acinetobacter (1 isolate), Staphylococcus (1 isolate), Achromobacter (1 isolate), Klebsiella (1 isolate), Cedecea (1 isolate) and Stenotrophomonas (1 isolate). Six bacterial isolates (A3 from A site, B4 from B site and F2, F3, F4 and F5 from F site) were identified as new strains and their sequences were deposited at the National Center for Biotechnical Information (NCBI) under the Genbank accession number MT261834 (Bacillus subtilis strain IRQNWYA3), MT261835 (Bacillus licheniformis strain IRQNWYB4), MT261836 (Pseudomonas stutzeri strain IRQNWYF2), MT261837 (Pseudomonas zhaodongensis strain 
IRQNWYF3), MT261838 (Pseudomonas sp. IRQNWYF4) and MT261839 (Bacillus licheniformis strain IRQNWYF5). Figure (2) demonstrated the frequency distribution of biosurfactant-producing genera within each site. Pseudomonas and Bacillus genera are the most distribution genera in four sites. Phylogenetic tree was constructed based on $16 \mathrm{~S}$ rRNA gene sequences of biosurfactant-producing bacteria to evaluate their close relationship and evolution between them. The analysis of phylogenetic tree placed eight Bacillus isolates into five subgroups. The first subgroup included Bacillus pumilus and Bacillus safensis along with closely related species. The second sub-group included Bacillus subtilis and Bacillus velezensis. The third sub-group comprised $B$. licheniformis. The fourth and fifth sub-group consisted of B. cereus and B. jeotgali respectively. The Pseudomonas species and their closely related species placed into three sub-groups, including $P$. aeruginosa, $P$. stutzeri, and $P$. mendocina each sub-group, respectively. The other biosurfactant producing bacteria were placed in different sub-groups with their closely related species (Figure 3).

\section{Discussion}

The present study is aimed to isolate biosurfactant producing bacteria from different sources contaminated with petroleum products including samples of crude oil and contaminated water of Al-Garraf oilfield. Biosurfactant producing bacteria can be isolated from various ecosystems, but the habitats that are polluted with petroleum products are more yielding than unpolluted habitats (Soltanighias 2019). The biosurfactant may be involved in protection of microorganisms against unfavorable environmental conditions. In addition, biosurfactant production is important for survival of the microorganisms to facilitate the attachment and adhesion of microbial cells to natural substrates (Fenibo 2019). The bacterial isolates that gave positive results for primary screening tests were only selected as biosurfactant producers. Where, the primary screening tests that selected to present study (emulsification index, Oil spreading test, and emulsification activity) constitutes a quick and easy method to screen and predict biosurfactant production. About $60 \%$ (20 isolates) of total isolates (33 isolates) are recorded as biosurfactant producing bacteria. Satpute et al. (2008) who found that identification of potential biosurfactant producers should be selected by more than one screening method.

Table 2. Identification of biosurfactant-producing bacteria by $16 \mathrm{~S}$ rRNA gene sequencing

\begin{tabular}{|c|c|c|c|c|c|}
\hline Site & $\begin{array}{c}\text { Isolates } \\
\text { code }\end{array}$ & $\begin{array}{c}\text { Accession no. of closet } \\
\text { species }\end{array}$ & Closet species & $\begin{array}{c}\text { Sequence } \\
\text { identity }(\%)\end{array}$ & $\begin{array}{c}\text { Accession no. of } \\
\text { new strain }\end{array}$ \\
\hline \multirow[t]{6}{*}{ A } & A1 & GU204966.1 & Pseudomonas mendocina & 100 & \\
\hline & $\mathrm{A} 2$ & MK607451.1 & Pseudomonas aeruginosa & 100 & \\
\hline & A3 & JF932296.1 & Bacillus subtilis & 99 & MT261834.1 \\
\hline & A4 & MN932266.1 & Aerococcus viridans & 100 & \\
\hline & A5 & KX657687.1 & Klebsiella pneumoniae & 100 & \\
\hline & A6 & MK859966.1 & Bacillus cereus & 100 & \\
\hline \multirow[t]{6}{*}{ B } & B1 & GU551935.1 & Bacillus cereus & 100 & \\
\hline & $\mathrm{B} 2$ & KY492312.1 & Enterobacter cloacae & 100 & \\
\hline & B3 & MN513224.1 & Aerococcus viridans & 100 & \\
\hline & B4 & KY328838.1 & Bacillus licheniformis & 99 & MT261835.1 \\
\hline & B5 & MT040837.1 & Bacillus subtilis & 100 & \\
\hline & B6 & KF783212.1 & Pseudomonas stutzeri & 100 & \\
\hline \multirow[t]{5}{*}{$\mathrm{C}$} & $\mathrm{C} 1$ & MF996504.1 & Stenotrophomonas sp. strain YFC1.2 & 100 & \\
\hline & $\mathrm{C} 2$ & MN022536.1 & Achromobacter sp. strain RABA7 & 100 & \\
\hline & C3 & LN999937.1 & Bacillus safensis & 100 & \\
\hline & $\mathrm{C} 4$ & GU339277.1 & Pseudomonas stutzeri & 100 & \\
\hline & $\mathrm{C} 5$ & MN365041.1 & Bacillus velezensis & 100 & \\
\hline \multirow[t]{4}{*}{$\mathrm{D}$} & D1 & MK521069.1 & Bacillus pumilus & 100 & \\
\hline & D2 & MK883070.1 & Staphylococcus epidermidis & 100 & \\
\hline & D3 & KR347228.1 & Bacillus jeotgali & 100 & \\
\hline & D4 & KX585258.1 & Pseudomonas stutzeri & 100 & \\
\hline \multirow[t]{7}{*}{$\mathrm{E}$} & E1 & EU258608.1 & Acinetobacter venetianus & 100 & \\
\hline & E2 & MK459527.1 & Enterobacter sp. strain TC159 & 100 & \\
\hline & E3 & MG516114.1 & Cedecea neteri & 100 & \\
\hline & E4 & KJ184910.1 & Enterobacter sp. CZGRN4 & 100 & \\
\hline & E5 & MK522131.1 & Enterobacter asburiae & 100 & \\
\hline & E6 & MK641315.1 & Enterobacter tabaci & 100 & \\
\hline & E7 & GQ406570.1 & Enterobacter cloacae & 100 & \\
\hline \multirow[t]{5}{*}{$\mathrm{F}$} & F1 & KJ437489.1 & Bacillus cereus & 100 & \\
\hline & $\mathrm{F} 2$ & MH384990.1 & Pseudomonas stutzeri & 99 & MT261836.1 \\
\hline & F3 & MH725483.1 & Pseudomonas zhaodongensis & 99 & MT261837.1 \\
\hline & $\mathrm{F} 4$ & LT601028.1 & Pseudomonas sp. A31/70 & 99 & MT261838.1 \\
\hline & F5 & HM753621.1 & Bacillus licheniformis & 99 & MT261839.1 \\
\hline
\end{tabular}




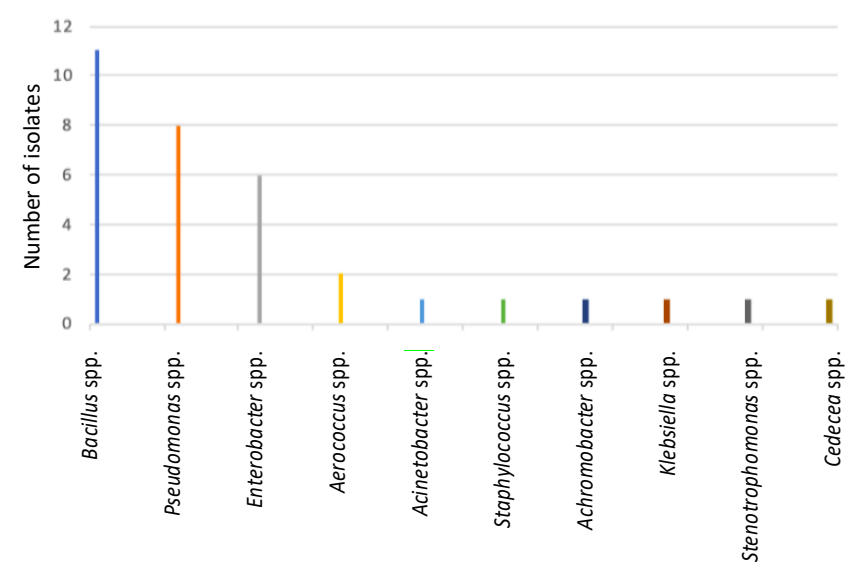

Figure 1. The number of total isolates of the respective genera $(n=33)$

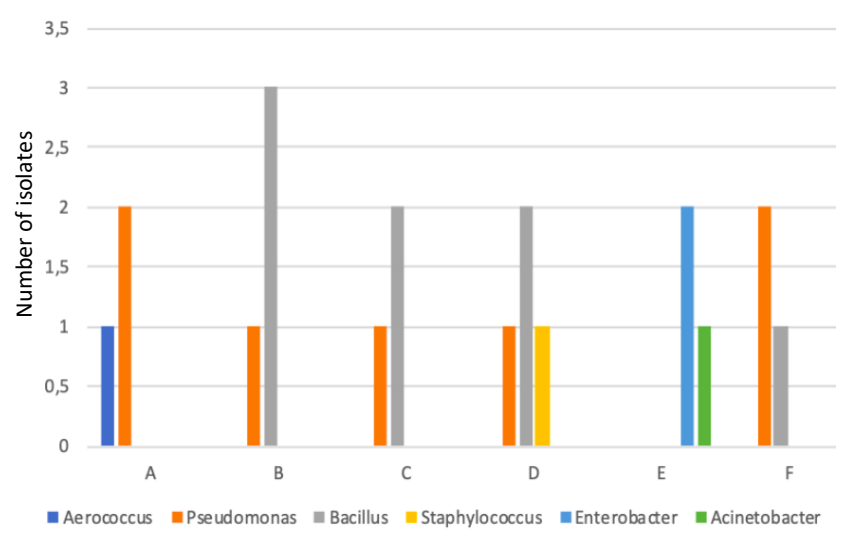

Figure 2. Distribution of biosurfactant producing bacteria at various sites

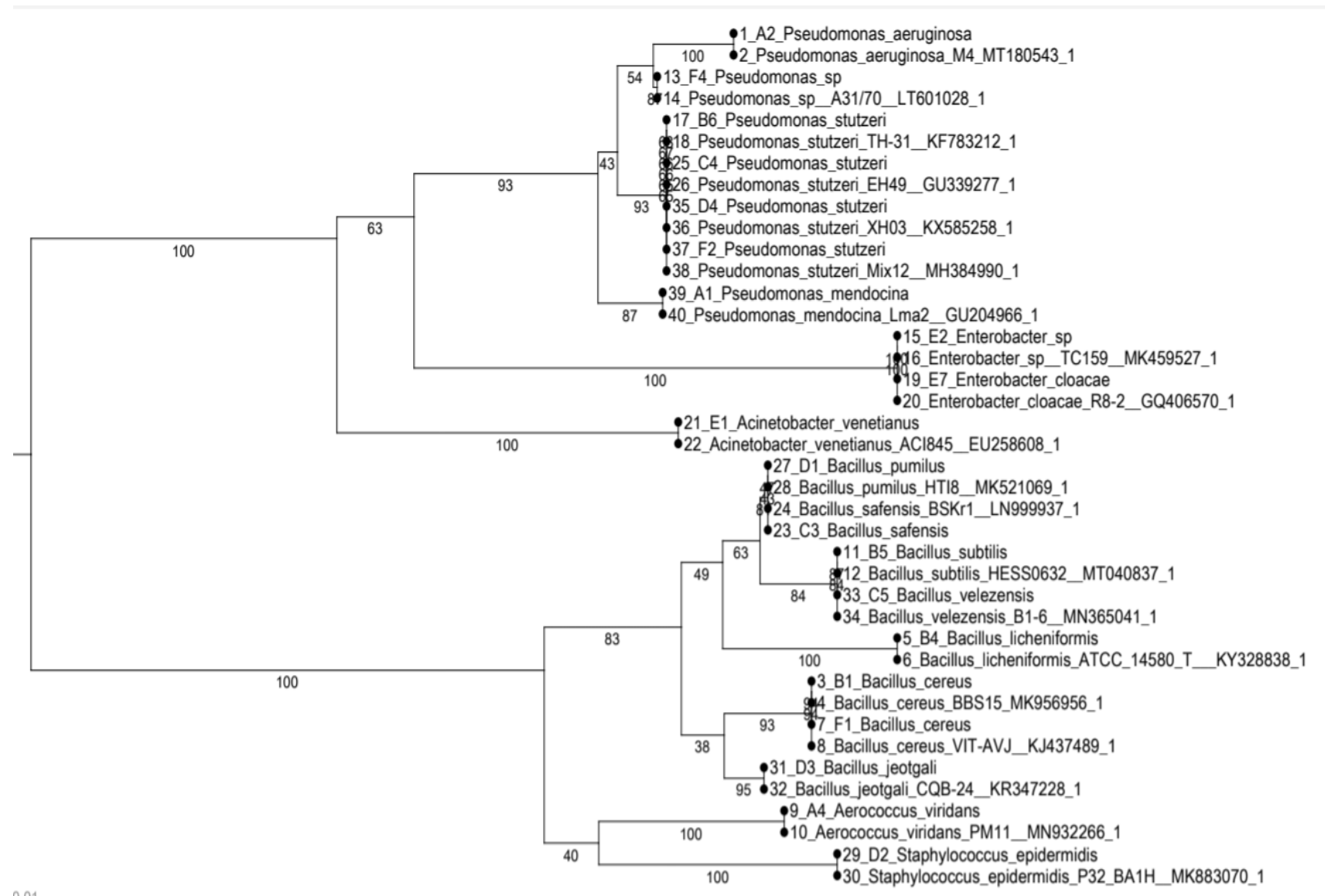

Figure 3. Neighbor-joining phylogenetic reconstruction tree showing evolutionary relationships of biosurfactant producing bacteria with close relatives available in NCBI GenBank database

Emulsification index (E24\%) is one of the important methods to support the selection of potential biosurfactant producers. The low values of emulsification index indicate that the isolates produce a low amount of biosurfactant. Mounira and Abdelhadi (2015) indicated that the oil spreading test is reliable in detecting biosurfactant production and determining the presence of biosurfactant in the supernatant of culture broth. Soltanighias et al. (2019) reported $29 \%$ of bacteria were isolated from three oilcontaminated considering as biosurfactant producing bacteria. While, Dang et al. (2015) were isolated 176 marine bacteria from hydrocarbon-contaminated sites along the Norwegian coastline. Eighteen isolates among them showed the ability to produce biosurfactants. The 
identification of bacteria based on 16S rRNA gene sequences showed nine isolates of biosurfactant producing bacteria belong to Bacillus genus, six isolates to Pseudomonas, two isolates to Enterobacter, one strain of Staphylococcus and Aerococcus.

The isolates of Bacillus and Pseudomonas genera are dominated in the study sites (figure 3 ). The species of the genus Pseudomonas distributed in five sites out six sites, while the species of the genus Bacillus distributed in four sites out six sites. The Pseudomonas is prevalent genera due to the diversity of mechanisms by which Pseudomonas promotes its survival and persistence in various environments (Moradali et al. 2017). The Bacillus is predominant and prevalent genera in the hydrocarboncontaminated environments due to their ability of Bacillus to produce biosurfactants and presence of their resistant endospores, therefore they have been termed the more tolerant bacteria to high levels of hydrocarbon contaminants (Viramontes-Ramos et al. 2010).

The isolates of Bacillus (Bacillus subtilis, Bacillus licheniformis, Bacillus cereus, Bacillus pumilus, Bacillus safensis, and Bacillus velezensis) were obtained in the current study have been reported for biosurfactant production in several previous studies (Liu et al. 2010; Joshi et al. 2013; Yadav et al. 2016; Das and Kumar 2019). A large variety of the Bacillus genus has been reported for biosurfactants production mainly a variety of lipopeptides biosurfactants, and the majority of Bacillus spp. are nonpathogenic, which allow their direct applications in food and pharmaceutical industries (Felix et al. 2019). Bacillus jeotgali was not reported for biosurfactant production in previous studies and was isolated for the first time from a Korean traditional fermented seafood, jeotgal in 2001 (Yoon et al. 2001), but in the current study, B. jeotgali isolated from crude oil in oilfield reservoir and reported its ability to produce biosurfactant for the first time in the world. Aerococcus viridans was not reported for biosurfactant production in previous studies, However, it is a saprophytic bacterium found in air, vegetation, soil, seafood and could be also found in the upper respiratory tract of healthy individuals as part of the microflora (Bradley 2002).

The member of Pseudomonas genus ( $P$. aeruginosa, $P$. stutzeri, and $P$. mendocina) was obtained in the current study have been widely studied for their production rhamnolipids and lipoproteins biosurfactant, where rhamnolipid biosurfactants have excellent surfactant properties (Cheng et al. 2017; Shekhar et al. 2018; Twigg et al. 2019). Acinetobacter venetianus, Enterobacter cloacae, and Staphylococcus epidermidis have been reported for the production of biosurfactant in previous reports (Bach et al. 2003; Hamed et al. 2012; Ekprasert et al. 2019). The microbial biosurfactants are very important compounds that can be used in various areas of application such as the pharmaceutical application, agriculture, food industries, enhanced oil recovery and environmental restoration (Liu et al. 2013; Lovaglio et al. 2015). The production of biosurfactants in large amounts for industrial applications depends on the optimization of the media composition and condition, primarily carbon, $\mathrm{pH}$, temperature, and nitrogen sources.

\section{ACKNOWLEDGMENTS}

The authors kindly acknowledge the deanship of College of Science, University of Basrah, Iraq for providing laboratory facilities.

\section{REFERENCES}

Antoniou E, Fodelianakis S, Korkakaki E, Kalogerakis N. 2015. Biosurfactant production from marine hydrocarbon-degrading consortia and pure bacterial strains using crude oil as carbon source. Front Microbiol 6: 274. DOI: 10.3389/fmicb.2015.00274

Bach H, Berdichevsky Y, Gutnick D. 2003. An exocellular protein from the oil-degrading microbe Acinetobacter venetianus RAG-1 enhances the emulsifying activity of the polymeric bioemulsifier emulsan. Appl Environ Microbiol 69: 2608-2615. DOI: 10.1128/AEM.69.5.26082615.2003

Banat IM, Satpute SK, Cameotra SS, Patil R, Nyayanit NV. 2014. Cost effective technologies and renewable substrates for biosurfactant production. Front Microbiol 5: 697. DOI: 10.3389/fmicb .2014.00697

Bradley A. 2002. Bovine mastitis: An evolving disease. Veter J 164 (2): 116-128. DOI: $10.1053 /$ tvj1.2002.0724

Cheng T, Liang J, He J, Hu X, Ge Z, Liu J. 2017. A novel rhamnolipidproducing Pseudomonas aeruginosa ZS1 isolate derived from petroleum sludge suitable for bioremediation. AMB Expr 7 (1): 120. DOI 10.1186/s13568-017-0418-X

Dang NP, Landfald B, Willassen NP. 2015. Biological surface-active compounds from marine bacteria. Environ Technol 37 (9): 11511158. DOI: 10.1080/09593330.2015.1103784

Das AJ, Kumar R. 2019. Production of biosurfactant from agro-industrial waste by Bacillus safensis $\mathrm{J} 2$ and exploring its oil recovery efficiency and role in restoration of diesel contaminated soil. Environ Technol Innov 16: 100450. DOI: 10.1016/j.eti.2019.100450

Deng MC, Li J, Liang FR, Yi M, Xu XM, Yuan JP, Peng J, Wu CF, Wang JH. 2014. Isolation and characterization of a novel hydrocarbondegrading bacterium Achromobacter sp. HZ01 from the crude oilcontaminated seawater at the Daya Bay, Southern China. Mar Pollut Bull 83 (1): 79-86. DOI: 10.1016/j.marpolbul.2014.04.018

Ekprasert J, Laopila K, Kanakai S. 2019. Biosurfactant production by a newly isolated Enterobacter cloacae B14 capable of utilizing spent engine oil. Pol J Environ Stud 28 (4): 2603-2610. DOI: $10.15244 /$ pjoes/92120

Elazzazy AM, Abdelmoneim TS, Almaghrabi OA. 2015. Isolation and characterization of biosurfactant production under extreme environmental conditions by alkali-halo-thermophilic bacteria from Saudi Arabia. Saudi J Biol Sci 22 (4): 466-475. DOI: 10.1016/j.sjbs.2014.11.018

Ewida AYI, Mohamed WSE. 2019. Isolation and characterization of biosurfactant producing bacteria from oil-contaminated water. Biosci Biotech Res Asia 16 (4): 833-841.

Femi-Ola T, Oluwole O, Olowomofe T, Yakubu H. 2015. Isolation and screening of biosurfactant producing bacteria from soil contaminated with domestic waste water. Br J Environ Sci 3: 58-63.

Felix AKN, Martins JJL, Almeida JGL, Giro MEA, Cavalcante KF, Melo VM, Pessoa ODL, Rocha MVP, Gonçalves LRB, Aguiara RSS. 2019. Purification and characterization of a biosurfactant produced by Bacillus subtilis in cashew apple juice and its application in the remediation of oil-contaminated soil. Colloids Surf B 175: 256263. DOI: $10.1016 /$ j.colsu rfb.2018.11.062

Fenibo EO, Ijoma GN, Selvarajan R, Chioma B, Chikere CB. 2019. Microbial surfactants: The next generation multifunctional biomolecules for applications in the petroleum industry and its associated environmental remediation. Microorganisms 7: 581. DOI: 10.3390/microorganisms7110581

Joshi SJ, Suthar H, Yadav AK, Hingurao K, Nerurkar A. 2013. Occurrence of biosurfactant producing Bacillus spp. in diverse habitats. ISRN Biotechnol. DOI: 10.5402/2013/652340 
Hamed SB, Smii L, Ghram A, Maaroufi A. 2012. Screening of potential biosurfactant-producing bacteria isolated from seawater biofilm. Afr J Biotechnol 11 (77): 14153-14158. DOI: 10.5897/AJB12.562

Katoh K, Misawa K, Kuma K, Myata T. 2002. MAFFT: A fast novel method for rapid multiple sequence alignment based on Fourier transform. Nucleic Acids Res 30 (14): 3059-3066. DOI: 10.1093/nar/gkf436

Liu J, Chen Y, Xu R, Jia Y. 2013. Screening and evaluation of biosurfactant-producing strains isolated from oilfield wastewater. Indian J Microbiol 53 (2): 168-174. DOI: 10.1007/s12088-013-0379$\mathrm{y}$

Liu X, Ren B, Chen M, Wang H, Kokare CR, Zhou X, Wang J, Dai H, Song F, Liu M, Wang J, Wang S, Zhang L. 2010. Production and characterization of a group of bioemulsifiers from the marine Bacillus velezensis strain H3. Appl Microbiol Biotechnol 7 (5): 1881-1893. DOI 10.1007/s00253-010-2653-9

Lovaglio RB, Silva VL, Ferreira H, Hausmann R, Contiero J. 2015 Rhamnolipids know-how: Looking for strategies for its industrial dissemination. Biotechnol Adv 33: 1715-1726. DOI: 10.1016/j.biotechadv.2015.09.002

Miyoshi T, Iwatsuki T, Naganuma T. 2005. Phylogenetic characterization of $16 \mathrm{~S}$ rRNA gene clones from deep-groundwater microorganisms that pass through 0.2-micrometer pore-size filters. Appl Environ Microbiol 71 (2): 1084-1088. DOI: 10.1128/AEM.71.2.1084 1088.2005

Moradali MF, Ghods S, Rehm BHA. 2017. Pseudomonas aeruginosa lifestyle: A paradigm for adaptation, survival, and persistence. Front Cell Infect Microbiol 7. DOI: 10.3389/fcimb.2017.00039

Mounira A, Abdelhadi G. 2015. Assessment of four different methods for selecting biosurfactant producing extremely halophilic bacteria. Afr J Biotechnol 14 (21): 1764-1772. DOI: 10.5897/AJB2015.14611

Ndlovu T, Khan S, Khan W. 2016. Distribution and diversity of biosurfactant-producing bacteria in a wastewater treatment plant. Environ Sci Pollut Res 23 (10): 9993-10004. DOI: 10.1007/s11356016-6249-5

Ozdal M, Gurkok S, Ozdal OG. 2017. Optimization of rhamnolipid production by Pseudomonas aeruginosa OG1 using waste frying oil and chicken feather peptone. 3 Biotech 7: 117. DOI 10.1007/s13205017-0774-x

Thavasi R, Subramanyam Nambaru VRM, Jayalakshmi S Balasubramanian T, Banat IM. 2011. Biosurfactant production by Pseudomonas aeruginosa from renewable resources. Indian J Microbiol 51 (1): 30-36. DOI: 10.1007/s12088-011-0076-7

Twigg M, Tripathi L, Zompra K, Salek K, Irorere V, Gutierrez T, Spyroulias G, Marchant R, Banat I. 2019. Surfactants from the sea: Rhamnolipid production by marine bacteria. Access Microbiol 1 (1A). DOI: 10.1099/acmi.ac2019.po0066
Santos APP, Silva MDS, Costa EVL, Rufino RD, Santos VA, Ramos CS, Sarubbo LA, Porto, ALF. 2018. Production and characterization of a biosurfactant produced by Streptomyces sp. DPUA 1559 isolated from lichens of the Amazon region. Braz J Med Biol Res 51 (2): e6657. DOI: 10.1590/1414-431X20176657

Satpute SK, Bhawsar BD, Dhakephalkar PK, Chopade BA. 2008. Assessment of different screening methods for selecting biosurfactant producing marine bacteria. Ind J Mar Sci 37: 243-250.

Satpute SK, Banpurkar AG, Dhakephalkar PK, Banat IM, Chopade BA. 2010. Methods for investigating biosurfactants and bioemulsifiers: A review. Crit Rev Biotechnol 30 (2): 127-144. DOI: 10.3109/07388550903427280

Sifour M, Ouled-Haddar H, Aziz GM. 2005. Production of biosurfactants from two Bacillus species. Egypt J Aquat Res 31: 142-148.

Shekhar S, Sundaramanickam A, Saranya K, Meena M, Kumaresan S, Balasubramanian T. 2018. Production and characterization of biosurfactant by marine bacterium Pseudomonas stutzeri (SSASM1). Int J Environ Sci Technol 16: 4697-4706. DOI: 10.1007/s13762-018-1915-4

Sohail R, Jamil N. 2020. Isolation of biosurfactant producing bacteria from Potwar oil fields: Effect of non-fossil fuel-based carbon sources. Green Process Synth 9: 77-86. DOI: 10.1515/gps-2020-0009.

Soltanighias T, Singh AEA, Satpute SK, Banpurkar AG, Koolivand A, Rahi P. 2019. Assessment of biosurfactant-producing bacteria from oil-contaminated soils and their hydrocarbon degradation potential. Environ Sustain. DOI: 10.1007/s42398-019-00074-0.

Vedaraman N, Venkatesh N. 2011. Production of surfactin by Bacillus subtilis MTCC 2423 from waste frying oils. Brazil J Chem Eng 28 (2): 175-180

Viramontes-Ramos S, Portillo-Ruiz MC, Ballinas-Casarrubias MDL, Torres-Muñoz JV, Rivera-Chavira BE, Nevárez-Moorillón GV. 2010. Selection of biosurfactan/bioemulsifier-producing bacteria from hydrocarbon-contaminated soil. Brazil J Microbiol 41 (3): 668675. DOI: 10.1590/s1517-83822010000300017

Xiangsheng Z, Miao L, Tingsheng X. 2010. Genetic modification of MEOR bacterium Bacillus licheniformis $\mathrm{H}$ strain by low energy ion beam irradiation. Open Biotechnol J 4: 14-17.

Yadav AK, Manna SKP, Singh A, Kumar M, Chakdar H, Kashyap PL, Srivastava AK. 2016. Isolation and characterization of biosurfactant producing Bacillus sp. from diesel fuel-contaminated site. Microbiol 85 (1): 56-62. DOI: 10.1134/s0026261716010161

Yoon JH, Kang SK, Lee KC, Kho YH, Choi SH, Kang KH, Park YH. 2001. Bacillus jeotgali sp. nov., isolated from jeotgal, Korean traditional fermented seafood. Intl J Syst Evol Microbiol 51: 10871092. DOI: $10.1099 / 00207713-51-3-1087$ 